\title{
Pengaruh Komitmen Profesi dan Perilaku Etis Terhadap Pencegahan Fraud
}

\author{
Sabirin \\ IAIN Pontianak \\ Kota Pontianak, Indonesia
}

\begin{abstract}
Abstrak
Tujuan penelitian adalah menguji dan menganalisis pengaruh komitmen profesi dan prilaku etis terhadap pencegahan fraud Pada PT XXX di Kota Pontianak. Penilitian ini bersifat kausal (causal research). Sumber data dalam penelitian ini adalah data primer berupa kuesioner.Populasi penelitian adalah seluruh karyawan yang ada di PT XXX yaitu sejumlah 8.762 karyawan. Adapun, metode pengambilan sampel yaitu menggunakan simple random sampling. Berdasarkan perhitungan terpilih sampel dalam penelitian ini adalah sejumlah 383 responden. Dalam penelitian ini dilakukan analisis statistik deskriptif dengan menggunakan teknik analisis regresi berganda. Hasil penelitian menunjukan bahwa variabel komitmen profesi dan perilaku etis berpengaruh positif dan siginifikan terhadap pencegahan fraud yang artinya semakin tinggi Komitmen Profesi, dan semakin baiknya prilaku etis karyawan maka semakin baik pula pencegahan fraud.
\end{abstract}

Kata Kunci : Komitmen Profesi, Prilaku Etis dan Pencegahan Fraud.

\begin{abstract}
The purpose of the study was to examine and analyze the effect of professional commitment and ethical behavior on fraud prevention at PT XXX in Pontianak City. This research is causal (causal research). The source of data in this study is primary data in the form of a questionnaire. The research population is all employees at PT XXX, which are 8,762 employees. Meanwhile, the sampling method is using simple random sampling. Based on the calculation, the selected sample in this study was 383 respondents. In this study, descriptive statistical analysis was performed using multiple regression analysis techniques. The results show that the variables of professional commitment and ethical behavior have a positive and significant effect on fraud prevention, which means that the higher the Professional Commitment, and the better the ethical behavior of employees, the better the prevention of fraud.
\end{abstract}

Keywords: Professional Commitment, Ethical Behavior and Fraud Prevention. 


\section{PENDAHULUAN}

Kecurangan adalah bentuk penipuan yang disengaja dilakukan sehingga dapat menimbulkan kerugian tanpa disadari oleh pihak yang dirugikan tersebut, serta memberikan kerugian kepada pelaku kecurangan (Alison, 2006). Kasus kecurangan dan pelanggaran operasional masih menjadi perbincangan dan selalu menjadi pemberitaan diberbagi media massa.

Berdasarkan survei yang dilakukan oleh Association of Certified Fraud Examiners (ACFE) Chapter Indonesia terhadap 229 responden yang terdiri dari pemegang sertifikasi Certified Fraud Examiners (CFE), anggota Association of Certified Fraud Examiners (ACFE), auditor, dan praktisi menunjukan sebanyak 154 responden atau sebesar $67 \%$ responden memilih korupsi, penyalahgunaan aset dipilih oleh 71 responden atau $31 \%$ dari jumlah respondn, sementara itu sisanya 4 responden atau sebanyak $2 \%$ memilih fraud berupa laporan keuangan (Survei fraud Indonesia, 2016). Banyaknya kasus fraud ini juga menyebabkan perhatian yang meningkat pula terhadap penyelidikan kasus kecurangan diberbagai organisasi.

Satu diantara contoh kasus yaitu perbedaan pencatatan penyimpanan dana kelompok usaha group bakri di PT. Bank Capital Indonesia Tbk ini misalnya. Terdapat tujuh emiten grup bakri dalam laporan keuangan mereka mengklaim menyimpan dana dengan total Rp. 9.07 triliun, namun bank capital disisi lain menyebutkan jumlah dana pihak ketiga di bank tersebut hanya Rp. 2.69 triliun. Selanjutnya, kasus yang terjadi pada bulan maret lalu yaitu Operasi Tangkap Tangan (OTT) yang dilakukan oleh Komisi Pemberantasan Korupsi (KPK) kepada salah satu direktur PT Krakatau Steel Tbk. Hasil OTT tersebut berhasil mengungkapkan bahwa Direktur Teknologi dan Produksi Krakatau Steel, Wisnu Kuncoro, sebagai tersangka penerima suap dari kontraktor yakni Kenneth Sutardja dan Kurniawan Eddy Tjokro (Yudi) dengan seorang perantara Alexander Muskitta dalam kasus pengadaan kebutuhan barang dan peralatan di Krakatau Steel. (upperline : Media Korporasi Indonesia).

Tindak kecurangan ini tentunya dapat dicegah diantaranya dapat dilakukan dengan menumbuhkan komitmen profesi, mengedepankan Perilaku Etis serta menumbuhkan niat untuk melakukan pelaporan terhadap pelanggaran/kecurangan atau Whistle blowing. Komitmen profesi menuntut seorang karyawan menjunjung tinggi nilai-nilai dan norma yang berlaku sesuai dengan standar profesional yang ada, sehingga mampu bertindak secara profesional. Seorang yang profesional dalam melaksanakan tugas dan pekerjaannya pasti akan berdasarkan pada perilaku, sikap dan orientasi terhadap profesinya tersebut. Seorang yang menjunjung tinggi komitmen terhadap profesi akan melakukan pencegahan dalam bersikap yang tidak sesuai dengan standar profesional, sehingga akan berupaya melakukan pencegahan terhadap apabila terjadinya pelanggaran yang akan menuntut dirinya mengungkapkan pelanggaran tersebut.

Upaya pencegahan selanjutnya yang dapat dilakukan adalah dengan menerapkan Perilaku Etis. Perilaku etis merupakan bentuk perilaku yang sesuai dengan norma-norma atau kaidah sosial, sehingga dapat menciptakan budaya jujur dan etika yang menjadi pedoman dalam sebuah organisasi atau perusahaan. Chen dan Ni (2010) menyatakan bahwa perilaku etis merupakan sesuatu yang diterima moral sebagai sesuatu yang 'baik' dan 'benar' sebagai lawan dari 'buruk' atau 'salah' dalam peraturan khususnya. Seperti yang disebutkan oleh Ahearne et al. dalam Yuniarta dan Purnawati (2016) bahwa kinerja akan meningkat ketika pimpinan memberdayakan potensi karyawannya, serta kewenangan untuk melakukan kreatifitas dan pengambilan keputusan.

Perilaku etis dalam sebuah perusahaan dapat tercipta dengan adanya pengendalian internal. Dimana pengendalian internal ini akan memegang peran penting dalam sebuah organidasi agar dapat meminimalisir terjadinya kecurangan dan pengendalian intern yang efektif akan menutup peluang terjadinya perilaku tidak etis (Fauwzi, 2011). 
Tjahjono et al. (2013) juga menyatakan hal yang serupa bahwa pegawai merupakan pihak yang paling tahu mengenai terjadinya fraud di dalam perusahaan. Namun, fakta berdasarkan penelitian yang dilakukan oleh IBE bahwa satu dari empat karyawan atau pegawai yang sadar akan adanya kecurangan di tempat kerja, hanya separuh saja yang berani untuk melaporkan kecurangan tersebut, sisanya memilih untuk diam dan tidak melaporkannya (Purba, 2015).

Penelitian penting karena kecurangan atau fraud bisa terjadi kapan saja dan di perusahaan mana saja, apa lagi untuk perusahaan ber skala besar dengan jumlah karyawan yang besar. Banyaknya karyawan pada perusahaan tentu saja memerlukan pengelolaan sumber daya manusia yang baik. Hal inilah yang juga memerlukan pengawasan yang tidak hanya oleh atasan namun juga bagian personalia perusahaan, sehingga nantinya pelanggaran yang terjadi di perusahaan dapat diketahui dengan meningkatkan partisipasi karyawan dalam melaporkan pelanggaran.

Perbedaan penelitian ini dengan penelitian sebelumnya adalah pada teknik analisis yang digunakan, selain itu objek penelitian juga berbeda, dan struktur bisnis yang kompleks sehingga menjadikan penelitian layak untuk diteruskan. Berdasarkan permasalahan di atas, dan melihat pentingnya pencegahan fraud di dalam organisasi atau perusahaan maka penulis tertarik untuk meneliti kembali dengan fokus pada Karyawan yang bekerja di Perusahaan PT XXX dengan tujuan penelitian adalah menguji dan menganalisis dan pengaruh komitmen profesi dan prilaku etis terhadap pencegahan fraud Pada PT XXX.

\section{KAJIAN PUSTAKA}

\section{A. Theory of Reasoned Action}

Theory of Reasoned Action (TRA) diperkenalkan oleh Martin Fishbein dan Icek Ajzen. Dalam Teori menghubungkan antara keyakinan (believe), sikap (attitude), kehendak (intention) dan perilaku (behavior). Kehendak merupakan prediktor terbaik perilaku, artinya: jika ingin mengetahui apa yang akan dilakukan seseorang, cara terbaik adalah mengetahui kehendak orang tersebut (Fishbein dan Ajzen, 1975).

Konsep dalam teori ini adalah memfokuskan perhatian, yaitu mempertimbangkan sesuatu yang dianggap penting. Kehendak (intention) ditentukan oleh sikap dan norma subjektif. Komponen pertama mengacu pada sikap terhadap perilaku. Ini merupakan hasil dari memperimbangkan untung dan rugi perilaku tersebut (outcome of the behavior). Hal ini perlu untuk dipertimbangkan pentingnya konsekuen yang dapat terjadi terhadap individu (evaluation regarding the outcome). Dilain pihak, komponen norma subjektif atau sosial mengacu pada keyakinan seseorang terhadap bagaimana dan apa yang dipikirkan orang-orang yang dianggap penting dan motivasi seseorang untuk mengikuti pikiran tersebut (Fishbein dan Ajzen, 1975).

Praktik atau perilaku menurut Theory of Reasoned Action (TRA) dipengaruhi dengan niat, sedangkan niat dipengaruhi oleh sikap dan norma subyektif. Sikap dipengaruhi oleh keyakinan atas hasil dari tindakan yang telah lama. Norma subyektif dipengaruhi oleh keyakinan akan pendapat orang lain serta motivasi untuk mentaati pendapat tersebut. Secara lebih sederhana, teori ini mengatakan bahwa seseorang akan melakukan suatu perbuatan apabila ia memandang perbuatan itu positif dan bila ia percaya bahwa orang lain ingin agar ia melakukannya. (Noah, 2014).

\section{B. Komitmen Profesional}

https://journals.telkomuniversity.ac.id/jaf

E-ISSN 2581-1088 
Menurut kode etik profesi Ikatan Akuntan Indonesia (IAI) (2020), komitmen profesi adalah perwujudan dari kepatuhan dari peraturan yang berlaku dalam setiap melaksanakan tugasnya, juga dalam rangka untuk memenuhi tanggungjawab profesinya. Sementara itu menurut kode etik profesi akuntan publik yang diterbitkan oleh Institut Akuntan Publik Indonesia (IAPI) (2020), tidak ada perbedaan antara yang dimaksud oleh IAI, karena kode etik yang dikeluarkan oleh IAPI secara paralel dengan kode etik yang dikeluarkan oleh IAI, dan IAMI atau Ikatan Akuntan Manajemen Indonesia, yang mana sudah mendapakan dukungan dari pusat pembinaan profesi keuangan Kementrian Keuangan Republik Indonesia.

Menurut Shaub et al. (1993) dalam Hariyani \& Putra (2018) menekankan perlunya untuk dapat belajar komitmen profesional karena berkaitan terhadap karir seseorang yang merupakan bagian utama dalam hidupnya dan sebagai bentuk dedikasi terhadap profesinya didalam organisasi dengan menerima visi, misi dan tujuan dari nilai-nilai organisasi. Indikator komitmen profesi (Aranya, 1984):
a. Pengabdian pada profesi
b. Kewajiban sosial
c. Kemandirian
d. Keyakinan terhadap peraturan profesi
e. Hubungan dengan sesama profesi komitmen professional

\section{Perilaku Etis}

Menurut Ricky W. Griffin dan Ronald J. Ebert dalam Hesti (2012) perilaku etis adalah perilaku dengan norma-norma sosial yang diterima secara umum sehubungan dengan tindakan-tindakan yang benar. Perilaku etis dapat menentukan kualitas individu (karyawan) yang dapat dipengaruhi oleh faktor-faktor yang diperoleh dari luar, kemudian menjadi prinsip yang dijalani dalam bentuk perilaku tersebut. Perilaku etis dalam perusahaan dapat tercipta dengan adanya pengendalian internal dari pihak manajemen perusahaan. Pengendalian internal memegang peranan yang sangat penting untuk organisasi meminimalisir yang akan terjadinya pelanggaran fraud dan pengendalian internal yang lebih efektif (whistle blowing system) agar menutup peluang terjadinya tindakan perilaku tidak etis, Fauwzi (2011).

AICPA dalam Arens (2008:442) menyebutkan unsur-unsur kode perilaku yang menjadi indikator dalam penelitian ini, yaitu:

1) Kode Perilaku Organisasi

2) Perilaku Umum Pegawai

3) Aktivitas, Pekerjaan, dan Jabatan Direktur di Luar

4) Hubungan dengan Klien dan Pemasok

5) Berurusan dengan Orang dan Organisasi Luar

6) Komunikasi yang Sigap

7) Privasi dan Kerahasiaan

\section{Fraud}

Pencegahan fraud adalah uapaya atau usaha untuk menolak segala bentuk fraud atau perbuatan curang yng dilakukan pegawai yang berdampak pada merugikan bagi organisasi atau perusahaan. Pencegahan dapat dilakukan agar kecurangan atau fraud dalam perusahaan tidak terjadi, sehingga misi dan visi perusahaan dapat tercapai dan mampu mengangkat reputasi perusahaan menjadi lebih baik.

Arens (2008) menyatakan bahwa cara yang paling efektif untuk mencegah kecurangan yaitu menerapkan perilaku etis dalam organisasi atau perusahaan. Perilaku etis adalah perilaku 
yang sesuai dengan norma-norma sosial, sehingga dapat menciptakan budaya jujur dan etika yang menjadi pedoman dalam sebuah organisasi atau perusahaan. Dengan menerapkan nilainilai positif dalam perusahaan maka akan meningkatkan pula produktivitas karyawan yang didukung dengan meningkatnya motivasi serta bermuara pada kinerja organisasi.

Indikator pencegahan fraud dalam penelitian ini adalah keandalan pelaporan keuangan, efektivitas dan efisiensi operasi serta kepatuhan terhadap hukum \& peraturan yang berlaku

\section{E. Kerangka Pemikiran}

\section{Pengaruh Komitmen Profesi terhadap Pencegahan Fraud}

Shaub et al. (1993) dalam Hariyani \& Putra (2018) menekankan perlunya untuk belajar komitmen profesional karena berkaitan dengan karir seseorang yang merupakan bagian utama dalam hidupnya dan sebagai bentuk dedikasi seseorang terhadap profesinya didalam suatu organisasi dengan menerima tujuan dan nilai-nilai organisasi. Institute of Internal Auditors (IIA) menyatakan bahwa kecurangan meliputi serangkaian tindakan-tindakan tidak wajar dan ilegal yang secara sengaja dilakukan untuk menipu. Tindakan tersebut dapat dilakukan untuk keuntungan atau kerugian organisasi dan oleh orang-orang di luar maupun di dalam sebuah organisasi (Sawyer, 2003). Hasil penelitian Ramadhaniyati \& Hayati (2014) menyatakan Profesionalisme Auditor Internal berpengaruh signifikan dalam mencegah kecurangan (fraud) dengan koefisien negatif.

\section{H1 : Komitmen Profesi berpengaruh positif terhadap Pencegahan Fraud}

\section{Pengaruh Perilaku Etis terhadap Pencegahan Fraud}

Menurut Ricky W. Griffin dan Ronald J. Ebert dalam Hesti (2012) perilaku etis adalah perilaku yang sesuai dengan norma-norma sosial yang diterima secara umum sehubungan dengan tindakan-tindakan yang benar dan baik. Perilaku etis ini dapat menentukan kualitas individu (karyawan) yang dipengaruhi oleh faktor-faktor yang diperoleh dari luar yang kemudian menjadi prinsip yang dijalani dalam bentuk perilaku. Arens (2008) menyatakan bahwa cara yang paling efektif untuk mencegah kecurangan yaitu menerapkan perilaku etis dalam organisasi atau perusahaan. Perilaku etis adalah perilaku yang sesuai dengan norma-norma sosial, sehingga dapat menciptakan budaya jujur dan etika yang menjadi pedoman dalam sebuah organisasi atau perusahaan. Dengan menerapkan nilai-nilai positif dalam perusahaan maka akan meningkatkan pula produktivitas karyawan yang didukung dengan meningkatnya motivasi serta bermuara pada kinerja organisasi. Hasil penelitian Gaurina, Purnamawati, \& Atmadja (2017) menyatakan persepsi karyawan mengenai perilaku etis berpengaruh positif dan signifikan terhadap pencegahan fraud.

\section{H2 : Perilaku Etis berpengaruh positif terhadap Pencegahan Fraud}

\section{METODE, DATA, DAN ANALISIS}

\section{A. Metode}


Penelitian ini adalah penelitian deskriptif (descriptive research), yaitu penelitian yang didesain untuk mengumpulkan data yang menjelaskan karakteristik orang, kejadian atau situasi. Hal ini melibatkan pengumpulan data kualitatif (Sekaran dan Bougie, 2017: 111). Lebih lanjut bahwa penelitian ini akan mendeskripsikan atau meneliti karakteristik dari sekelompok manusia, objek, kondisi, ataupun peristiwa pada masa sekarang, yang bisa dilihat secara nyata dan ditunjang dengan pengamatan yaitu: 1) Komitmen Profesi, 2) Perilaku Etis, 3) Whistle Blowing, dan 4) Pencegahan Fraud.

Penelitian ini bersifat kausal (causal research) adalah inti dari pendekatan ilmiah untuk penelitian. Penelitian seperti ini menguji apakah satu variabel menyebabkan variabel yang lain berubah atau tidak (Sekaran \& Bougie: 2017: 112). Situasi penelitian ini bersifat tidak diatur (noncontrived setting) atau penelitian korelasional yang selalu dilakukan dalam situasi tidak diatur sehingga penelitian ini juga dapat dikategorikan pada penelitian studi lapangan (field study). Dengan kata lain peneliti hanya mengumpulkan data dan tidak melakukan intervensi apapun yang dapat mempengaruhi hasil (Sekaran \& Bougie: 2017: 115).

\section{B. Data Penelitian}

Sumber data pada penelitian ini adalah sumber primer. Data primer (primary data) mengacu pada informasi yang diperoleh langsung (dari tangan pertama) oleh peneliti terkait dengan variabel ketertarikan untuk tujuan tertentu dari studi. (Sekaran \& Bougue, 2017: 130). Metode pengumpulan data primer dilakukan dengan menggunakan kuesioner. Sedangkan data sekunder dalam penelitian ini diperoleh peneliti dari studi dokumentasi dengan cara mengumpulkan data dari dokumen-dokumen yang berhubungan dengan masalah yang diteliti.

Populasi penelitian adalah seluruh karyawan yang ada di PT XXX yaitu sejumlah 8.762 orang. Adapun rincian populasi tersebut dapat dilihat pada tabel berikut ini:

Tabel Daftar Rincian Populasi

\begin{tabular}{|l|l|c|}
\hline No & Keterangan & Jumlah (dalam Orang) \\
\hline 1. & RH (Regional Head) & 2 \\
\hline 2. & GM (General Manager) & 6 \\
\hline 3. & EM (Estate Manager) & 16 \\
\hline 4. & MM (Mill Manager) & 4 \\
\hline 5. & Askep (Asisten Kepala) & 12 \\
\hline 6. & AA (Asisten Afdeling) & 430 \\
\hline 7. & KBT (Karyawan Bulanan Tetap) & 3753 \\
\hline 8. & KHT (Karyawan Harian Tetap) & 4329 \\
\hline 9. & KHL (Karyawan Harian Lepas) & 129 \\
\hline 10. & TK (Tenaga Kontrak) & 8.762 \\
\hline \multicolumn{2}{|c|}{ Jumlah } & \\
\hline
\end{tabular}

Sumber: Data di Olah, 2021

Adapun, metode pengambilan sampel yaitu menggunakan simple random sampling, dikatakan simple (sederhana) karena pengambilan anggota sampel dari populasi dilakukan secara acak tanpa memperhatikan strata yang ada dalam populasi tersebut (Sugiyono, 2013). Penentuan ukuran sampel pada penelitian ini menggunakan rumus slovin:

$$
\frac{n=8.762}{1+N(\mathrm{e}) 2}
$$




$$
\begin{gathered}
\frac{\mathrm{n}=\quad 8.762}{1+8762(0,05)^{2}} \\
\mathrm{n}=382,62=383 \text { Orang }
\end{gathered}
$$

dimana:

$$
\begin{aligned}
& n \quad=\text { Jumlah Sampel } \\
& \mathrm{N} \quad=\text { jumlah populasi } \\
& \mathrm{e} \quad=\text { presentase kelongaaran ketidaktelitian (presisi) karena kesalahan } \\
& \text { pengambilan sampel yang masih dapat ditolerir }
\end{aligned}
$$

Berdasarkan perhitungan diatas, maka disimpulkan bahwa jumlah sampel dalam penelitian ini adalah sejumlah 383 responden.

\section{Variabel Penelitian}

Menurut Sekaran \& Bougue (2017: 2) pengukuran adalah penempatan angka atau simbol lain untuk ciri-ciri (atau atribut) objek sesuai dengan rangkaian peraturan yang dijelaskan sebelumnya. Lebih lanjut Sekaran \& Bougie (2017:2) menjelaskan bahwa langkah awal dalam proses operasionalisasi adalah mendefenisikan setiap konstruk dan pengukuran variable yang digunakan sebelum melakukan pengujian hipotesis penelitian.

Berikut definisi operasionalisasi masing-masing variable penelitian ini:

1. Variabel independen $(\mathrm{X})$ yang terdiri dari Komitmen Profesi $\left(\mathrm{X}_{1}\right)$ dan Perilaku Etis $\left(\mathrm{X}_{2}\right)$.
a) Variabel independen pertama $\left(\mathrm{X}_{1}\right)$ yaitu Komitmen Profesi
Komitmen Profesi adalah Ridho \& Rini (2013) menyatakan komitmen profesional sebagai kecintaan dan keteguhan hati seseorang dalam menjalankan pekerjaan yang diberikan berdasarkan aturan dan norma yang ada dalam profesinya. Adanya komitmen profesional ini diharapkan bisa membuat karyawan bekerja sesuai dengan kode etik profesi yang ada serta menjunjung tinggi nilai-nilai norma dan kejujuran dalam melakukan pekerjaan. Dalam penelitian ini, Komitmen Profesi diukur dari Pengabdian pada profesi, Kewajiban sosial, Kemandirian, Keyakinan terhadap peraturan profesi , Hubungan dengan sesama profesi komitmen profesional. Instrumen dalam penelitian ini adalah berupa pertanyaan dengan skala 1 (sangat tidak setuju) sampai dengan skala 5 (sangat setuju) untuk menentukan sikap responden atas pertanyaan yang diajukan.
b) Variabel independen kedua $\left(\mathrm{X}_{2}\right)$ yaitu Perilaku Etis
Perilaku Etis berarti perilaku etis adalah perilaku yang sesuai dengan norma- norma sosial yang diterima secara umum sehubungan dengan tindakan-tindakan yang benar dan baik. Perilaku etis ini dapat menentukan kualitas individu (karyawan) yang dipengaruhi oleh faktor-faktor yang diperoleh dari luar yang kemudian menjadi prinsip yang dijalani dalam bentuk perilaku. Variabel ini diukur melalui tanggungjawab, kepentingan publik, integritas, Objektivitas dan Independensi, Keseksamaan, Ruang Lingkup dan Sifat Jasa. Instrumen ini terdiri dari pertanyaan dengan skala 1 (sangat tidak setuju) sampai dengan skala 5 (sangat setuju) untuk menentukan sikap responden atas pertanyaan yang diajukan.

2. Variabel Dependen (Y) yaitu Pencegahan Fraud

Pencegahan Fraud adalah suatu upaya atau usaha untuk menolak atau menahan segala bentuk fraud atau perbuatan curang yang dilakukan pegawai yang berdampak merugikan bagi organisasi/perusahaan. Kewajaran ini menyangkut materialitas, posisi keuangan, dan arus kas. Pencegahan Fraud diukur dengan keandalan pelaporan 
keuangan, efektivitas dan efisiensi operasi serta kepatuhan terhadap hukum \& peraturan yang berlaku. Instrumen ini terdiri dari pertanyaan dengan skala 1 sampai dengan skala 5 untuk menentukan sikap responden atas pertanyaan yang diajukan.

\section{Analisis Data}

Teknik analisis yang digunakan dalam penelitian ini adalah metode analisis regresi linier berganda. Metode ini akan menggambarkan suatu hubungan dimana satu atau lebih variable bebas (variabel independen) mempengaruhi variabel lainnya (variabel dependen). Sebelum dilakukan pengujian atas hipotesis, terlebih dahulu akan dilakukan pengujian kualitas data dengan uji validitas dan uji reliabilitas serta uji asumsi klasik (meliputi uji multikolonieritas, uji normalitas dan uji heterogenitas).

\section{E. Pengujian Hipotesis}

\section{Koefisien Determinan $\left(R^{2}\right)$}

Koefisien determinasi mengukur seberapa jauh kemampuan model dalam menerangkan variasi variabel dependen (Ghazali, 2013). Hasil uji koefisien determinasi $\left(\mathrm{R}^{2}\right)$ menjelaskan seberapa besar kemampuan model atau interaksi antara komitmen profesi, prilaku etis (variabel independen) dalam menjelaskan pencegahan fraud (variabel dependen).

\section{Uji Statistik $F$}

Uji statistik F dilakukan dengan tujuan untuk menguji apakah semua variabel independen yang dimaksud dalam model mempunyai pengaruh secara bersama-sama terhadap variabel dependen. Secara bebas dengan signifikan sebesar 0,05 dapat disimpulkan (Ghozali, 2013).

Jika nilai signifikansi < 0,05 maka Ha diterima dan H0 ditolak. Ini berarti menyatakan bahwa semua variabel independen atau bebas mempunyai pengaruh secara bersama-sama terhadap variabel dependen atau terikat.

Jika nilai signifikansi > 0,05 maka Ha ditolak dan $\mathrm{H} 0$ diterima. Ini berarti menyatakan bahwa semua variabel independen atau bebas tidak mempunyai pengaruh secara bersama-sama terhadap variabel dependen atau terikat.

Pengujian hipotesis dilakukan melalui analisis regresi berganda. Model regresi berganda bertujuan untuk memprediksi besar variabel dependen dengan menggunakan data variabel independen yang sudah diketahui besarnya (Ghozali, 2013).

Persamaan analisis regresi linier berganda dirumuskan:

$$
\mathrm{Y}=\mathrm{a}+\mathrm{b} 1 \mathrm{X} 1+\mathrm{b} 2 \mathrm{X} 2+\mathrm{e}
$$

\section{Uji Statistik $t$}

Uji statistik t bertujuan untuk menguji seberapa jauh pengaruh satu variabel independen secara individual dalam menerangkan variasi variabel dependen (Ghazali, 2013). Hipotesis alternatif yang hendak diuji adalah sebagai berikut:

Ha: Masing-masing variabel independen berpengaruh terhadap variabel dependen 
Ada atau tidaknya pengaruh signifikan dari masing-masing variabel independen terhadap variabel dependen dapat diketahui dengan membandingkan nilai signifikannya dengan derajat kepercayaannya. Apabila tingkat signifikan lebih kecil dari 0,05 maka Ha diterima. Demikian pula sebaliknya jika tingkat signifikan lebih besar dari 0,05 maka Ha ditolak. Bila Ha diterima dan Ho ditolak berarti ada hubungan signifikan antara variabel independen dengan variabel dependen (Ghozali, 2013).

\section{HASIL DAN DISKUSI}

\section{A. Hasil Uji Validitas}

Pengujian validitas dilakukan dengan menggunakan metode Analisis korelasi. Perhitungan dilakukan dengan bantuan program SPSS. Nilai batas korelasi yang digunakan adalah lebih besar dari 0,3 atau signifikansi yang berada di bawah 0,05 menunjukkan sebagai item yang valid. Hasil pengujian menunjukkan bahwa untuk variabel komitmen profesi (X1) yang terdiri dari 13 item pertanyaan memiliki nilai korelasi di atas 0,3 dan signifikansi dibawah 0,05, sehingga dapat dikatakan bahwa item angket variabel komitmen profesi (X1) valid dan dapat digunakan untuk mengukur variabel yang diteliti. Variabel perilaku etis (X2), yang terdiri dari 11 item pertanyaan memiliki nilai korelasi di atas 0,3 dan signifikansi dibawah 0,05, sehingga dapat dikatakan bahwa item angket variabel perilaku etis (X2) valid dan dapat digunakan untuk mengukur variabel yang diteliti. Sementara itu variabel pencegahan fraud (Y) yang teridiri dari 11 item pertanyaan memiliki nilai korelasi di atas 0,3 dan signifikansi dibawah 0,05 , sehingga dapat dikatakan bahwa item angket variabel pencegahan fraud (Y) valid dan dapat digunakan untuk mengukur variabel yang diteliti

\section{B. Hasil Uji Realibilitas}

Tabel Hasil Uji Reabilitas

\begin{tabular}{|l|l|l|}
\hline Variabel & Alpha & Keterangan \\
\hline Komitmen Profesi & 0,868 & Relabel \\
\hline Prilaku Etis & 0,719 & Relabel \\
\hline Pencegahan Fraud & 0,789 & Relabel \\
\hline
\end{tabular}

Sumber : SPSS 23, data diolah

Berdasarkan hasil uji reliabilitas diperoleh hasil perhitungan yang menunjukkan nilai Cronbach's Alpha masing-masing variabel lebih besar dari 0,700. Artinya data yang dipergunakan dalam penelitian ini reliabel atau dapat dipercaya sehingga dapat dilanjutkan pada analisis berikutnya.

\section{Hasil Uji Normalitas}

Penelitian ini melakukan pengujian asumsi yaitu uji normalitas dengan uji Kolmogorov Smirnov. Hasil uji normalitas ditunjukan dibawah ini:

Tabel Hasil Uji Normalitas dengan Uji One Sample Kolmogorov-Smirnov 


\begin{tabular}{|c|c|}
\hline N & 257 \\
\hline Asymp. Sig. (2-tailed) & $0.200^{\mathrm{c}}$ \\
\hline
\end{tabular}

Sumber : SPSS 23, data diolah

Berdasarkan tabel tersebut terlihat bahwa nilai Asymp. Sig yang dihasilkan dari Kolmogorov-Smirnov Test bernilai sebesar 0,200 yang berarti berada di atas batas maksimum error yaitu 0,05 atau probabilitas > 0,05 sehingga dapat disimpulkan bahwa data di atas memiliki residu berdistribusi normal dan dapat digunakan dalam penelitian.

\section{Uji Heterokedastisitas}

Model regresi yang baik adalah yang Homoskesdatisitas atau tidak terjadi Heteroskesdatisitas. Salah satu uji statistik yang dapat digunakan untuk mendeteksi ada tidaknya heteroskedastisitas adalah Uji Glejser. Berikut ini akan disajikan perhitungan yang menunjukkan pengujian heterokedastisitas:

\section{Tabel Ringkasan Hasil Uji Heterokedastisitas Melalui Uji Gletser}

\begin{tabular}{|c|c|c|}
\hline Variabel & Sig & Keterangan \\
\hline X1 & 0,119 & Tidak terjadi Heterokedastisitas \\
\hline X2 & 0,227 & Tidak terjadi Heterokedastisitas \\
\hline Y & 0,579 & Tidak terjadi Heterokedastisitas \\
\hline
\end{tabular}

Sumber : SPSS 23, data diolah

Masing-masing variabel berada di atas batas maksimum error yaitu 0,05 atau probabilitas $>0,05$ sehingga dapat disimpulkan bahwa data di atas dapat disimpulkan bahwa model regresi tidak mengandung adanya Heteroskedastisitas. Hasil ini konsisten dengan uji sebelumnya.

\section{E. Hasil Uji Multikolinieritas}

Untuk mendeteksi ada atau tidaknya Multikolinearitas didalam model regresi dilihat dari hubungan antar variabel bebas yg ditunjukkan oleh angka tolerance dan variance inflation factor (VIF). Nilai cutoff yang umum dipakai untuk menunjukkan adanya multikolonieritas adalah nilai $=0.10$ atau sama dengan nilai $\mathrm{VIF}=10$. Berikut ini akan disajikan perhitungan yang menunjukkan pengujian multikolinieritas. Pengujian dilakukan dengan bantuan software SPSS Statistics diperoleh hasil uji Multikolinieritas sebagai berikut:

Tabel Ringkasan Hasil Uji Multikolinieritas

\begin{tabular}{|c|c|c|c|}
\hline Variabel & Tolerance & VIF & Keterangan \\
\hline X1 & 0,829 & 1.207 & Tidak terjadi Multikolinieritas \\
\hline X2 & 0,757 & 1.321 & Tidak terjadi Multikolinieritas \\
\hline Y & 0,781 & 1.280 & Tidak terjadi Multikolinieritas \\
\hline
\end{tabular}

Sumber :SPSS 23, data diolah

Dari output di atas terlihat bahwa semua variabel independen memiliki tolerance value atau nilai tolerasi kurang dari 1 dan VIF kurang dari 10. Hal ini menunjukkan bahwa tidak terdapat multikolinieritas diantara variabel-variabel independen sehingga data yang diperoleh dapat digunakan dalam penelitian. 


\section{F. Analisis Koefisien Determinasi}

Dalam suatu penelitian sering ingin diketahui seberapa besar hubungan atau pengaruh antara variabel-variabel bebas dengan variabel terikat. Selanjutnya untuk mengetahui besar pengaruh yang diberikan Komitmen Profesi (X1), Perilaku Etis (X2) terhadap Pencegahan fraud (Y) pada PT XXX dapat dilihat dari koefisien determinasi pada tabel di bawah ini:

Tabel Koefisien Determinasi

\begin{tabular}{|c|c|c|c|c|}
\hline Model & R & R Square & $\begin{array}{c}\text { Adjusted R } \\
\text { Square }\end{array}$ & $\begin{array}{c}\text { Std. Error of the } \\
\text { Estimate }\end{array}$ \\
\hline 1 & 0,474 & 0,225 & 0,216 & 3,11331 \\
\hline \multicolumn{4}{|l}{ Predictors : X2, X1, Z }
\end{tabular}

Sumber: Data Primer Diolah (2021).

Tabel diatas menunjukkan bahwa nilai koefisian determinasi atau Adjusted $\mathrm{R}^{2}$ bernilai sebesar 0,216 atau 21,6\%. Hal ini menunjukkaan bahwa variabel bebas secara bersama-sama mempengaruhi variabel terikat sebesar $21.6 \%$ sedangkan sisanya $78.4 \%$ dapat dijelaskan oleh variabel lain di luar model regresi di atas.

\section{G. Analisisi Uji Simultan (F)}

Pengujian secara simultan digunakan untuk mengetahui nilai yang memberikan kuatnya pengaruh atau hubungan dua variabel atau lebih secara bersama-sama. Kita dapat menguji secara simultan apakah model atau persamaan yang telah didapatkan secara bersama-sama berpengaruh terhadap Pencegahan fraud. Adapun hasil pengujian secara simultan / uji $\mathrm{F}$ statistik dapat dilihat pada tabel berikut :

Tabel Hasil Uji F Regresi Linear Berganda

\begin{tabular}{|c|c|c|c|}
\hline Model & Mean Square & F & Sig \\
\hline Regresi & 237.366 & 24,489 & 0,000 \\
\hline Residual & 9.693 & - & - \\
\hline Predictor X2, X1, \\
\hline
\end{tabular}

Dari tabel diatas diperoleh nilai signifikansi $\mathrm{F}$ sebesar 0,000 dan nilai $\mathrm{F}_{\text {hitung }}$ sebesar 24,489 sedangkan $F_{\text {tabel }}$ sebesar 3.07. Dengan nilai signifikansi yang lebih kecil dari 0,05 dan nilai $F_{\text {hitung }}$ lebih besar dari $\mathrm{F}_{\text {tabel }}$ maka dapat disimpulkan bahwa hipotesis $\mathrm{H}_{\mathrm{o}}$ ditolak, yang berarti pada tingkat signifikansi sebesar 5\% terdapat pengaruh yang signifikan secara simultan dari variabel Komitmen Profesi (X1), dan Perilaku Etis (X2). Sehingga dapat disimpulkan bahwa semua variabel X dan Y bersama-sama mampu memberikan pengaruh yang signifikan terhadap Pencegahan fraud.

\section{H. Hasil Uji Parsial (T)}

Hasil pengolahan software SPSS Statistics untuk analisis uji parsial disajikan pada tabel berikut:

\section{Tabel Hasil Uji Parsial}




\begin{tabular}{|c|c|c|c|c|}
\hline Model & B & Standardized Coefficients & t & Sig \\
\hline Constant & 18.934 & 0 & 6.515 & 0,000 \\
\hline X1 & 0,097 & 0,119 & 1.971 & 0,05 \\
\hline X2 & 0,254 & 0,268 & 4.229 & 0,000 \\
\hline \multicolumn{4}{|l}{ Variabel Dependent : Y }
\end{tabular}

Dengan df $=257-\mathrm{k}-1=131-2-1=255$, maka diperoleh $\mathrm{t}_{\text {tabel }}$ sebesar 1,652. Dari tabel diketahui untuk variabel Komitmen Profesi (X1) memiliki thitung sebesar 1.971 apabila dibandingkan dengan $t_{\text {tabel }}$ 1,652 maka diperoleh $t_{\text {hitung }}>t_{\text {tabel }}=1.971>1.660$. Sementara itu nilai signifikansi Komitmen Profesi adalah 0,05 apabila dibandingkan dengan $\alpha=5 \%$ maka diperoleh $0,05<0,05$. Dengan demikian $\mathrm{H}_{\mathrm{o} 3}$ ditolak, ini berarti secara parsial Komitmen profesi mempunyai pengaruh yang signifikan terhadap Pencegahan Fraud. Oleh karena itu semakin tinggi Komitmen Profesi maka akan semakin tinggi Pencegahan Fraud. Sementara Koefesien Beta Komitmen Profesi sebesar 0,097, hal ini menunjukan bahwa pengaruh Komitmen profesi sebesar 9.7\% terhadap Pencegahan Fraud.

Perilaku etis (X2) diketahui memiliki nilai thitung sebesar 4,229 apabila dibandingkan dengan nilai $t_{\text {tabel }} 1,652$ maka diperoleh $t_{\text {hitung }}>t_{\text {tabel }}=4,229>1,652$. Sementara itu nilai signifikansi Perilaku etis (X2) adalah 0,000 apabila dibandingkan dengan $\alpha=5 \%$ maka diperoleh $0,000<0,05$. Dengan demikian $\mathrm{H}_{04}$ ditolak, ini berarti secara parsial Perilaku Etis mempunyai pengaruh yang signifikan terhadap Pencegahan Fraud. Oleh karena itu semakin tinggi Perilaku Etis maka akan semakin tinggi Pencegahan Fraud. Sementara Koefesien Beta Perilaku Etis sebesar 0,254, hal ini menunjukan bahwa pengaruh Perilaku Etis sebesar 25.4\% terhadap Pencegahan Fraud.

\section{PEMBAHASAN}

\section{A. Pengaruh Komitmen Profesi terhadap Pencegahan Fraud pada PT XXX}

Berdasarkan hasil uji statistik variabel komitmen profesi berpengaruh positif dan siginifikan terhadap pencegahan fraud, yang artinya semakin tinggi Komitmen Profesi maka semakin baik pula pencegahan fraud. Hasil penelitian ini senada dengan penelitian yang menyatakan bahwa komitmen profesi berpengaruh terhadap pencegahan fraud. Shaub et al. (1993) dalam Hariyani \& Putra (2018) menekankan perlunya untuk belajar komitmen profesional karena berkaitan dengan karir seseorang yang merupakan bagian utama dalam hidupnya dan sebagai bentuk dedikasi seseorang terhadap profesinya di dalam suatu organisasi dengan menerima tujuan dan nilai-nilai organisasi. Institute of Internal Auditors (IIA) menyatakan bahwa kecurangan meliputi serangkaian tindakan-tindakan tidak wajar dan ilegal yang secara sengaja dilakukan untuk menipu. Tindakan tersebut dapat dilakukan untuk keuntungan atau kerugian organisasi dan oleh orang-orang di luar maupun di dalam sebuah organisasi (Sawyer, 2003). Hasil penelitian Ramadhaniyati \& Hayati (2014) menyatakan Profesionalisme Auditor Internal berpengaruh signifikan dalam mencegah kecurangan ( $f r a u d)$.

Dengan demikian, semua hal diatas dapat mendukung hasil dari penelitian ini yang mengungkapkan bahwa komitmen profesi berpengaruh positif dan signifikan terhadap pencegahan fraud pada PT XXX.

\section{B. Pengaruh Perilaku Etis terhadap Pencegahan Fraud Pada PT XXX}

Berdasarkan hasil uji statistik variabel perilaku etis berpengaruh positif dan siginifikan terhadap pencegahan fraud, yang artinya semakin tinggi perilaku etis maka semakin baik pula 
Pencegahan Fraud. Menurut Ricky W. Griffin dan Ronald J. Ebert dalam Hesti (2012) perilaku etis adalah perilaku yang sesuai dengan norma-norma sosial yang diterima secara umum sehubungan dengan tindakan-tindakan yang benar dan baik. Perilaku etis ini dapat menentukan kualitas individu (karyawan) yang dipengaruhi oleh faktor-faktor yang diperoleh dari luar yang kemudian menjadi prinsip yang dijalani dalam bentuk perilaku. Arens (2008) menyatakan bahwa cara yang paling efektif untuk mencegah kecurangan yaitu menerapkan Perilaku Etis dalam organisasi atau perusahaan. Perilaku etis adalah perilaku yang sesuai dengan normanorma sosial, sehingga dapat menciptakan budaya jujur dan etika yang menjadi pedoman dalam sebuah organisasi atau perusahaan. dengan menerapkan nilai-nilai positif dalam perusahaan maka akan meningkatkan pula produktivitas karyawan yang didukung dengan meningkatnya motivasi serta bermuara pada kinerja organisasi.

Hasil penelitian ini senada dengan penelitian Gaurina, Purnamawati, \& Atmadja (2017) menyatakan persepsi karyawan mengenai Perilaku Etis berpengaruh positif dan signifikan terhadap Pencegahan Fraud.

Dengan demikian, semua hal diatas dapat mendukung hasil dari penelitian ini yang mengungkapkan bahwa perilaku etis berpengaruh positif dan signifikan terhadap pencegahan fraud pada PT XXX.

\section{KESIMPULAN, KETERBATASAN, DAN SARAN}

\section{A. Kesimpulan}

Berdasarkan hasil penelitian dan pembahasan pada bab sebelumnya, maka kesimpulan yang dapat diambil adalah bahwa variabel Komitmen Profesi, Prilaku etis secara statistik berpengaruh siginifikan terhadap Pencegahan Fraud. Hal ini berarti bahwa semakin baik komitmen pegawai serta semakin baik prilaku etis pegawai akan semakin baik pula pencegahan fraud.

Hasil penelitian ini berimplikasi pada Theory of Reasoned Action (TRA) yang dikemukakan oleh Fishbein dan Ajzen (1975), teori ini mengatakan bahwa sikap dipengaruhi oleh keyakinan atas hasil dari tindakan yang telah lama. Norma subyektif dipengaruhi oleh keyakinan akan pendapat orang lain serta motivasi untuk mentaati pendapat tersebut. Sehingga dapat disimpulkan bahwa seseorang akan melakukan suatu perbuatan apabila ia memandang perbuatan itu positif dan bila ia percaya bahwa orang lain ingin agar ia melakukannya.

Hasil penelitian ini diharapkan menjadi bukti empiris untuk penelitian di masa yang akan datang dan dapat digunakan sebagai referensi dalam ilmu akuntansi terkait dengan akuntansi keperilakuan, Komitmen Profesi, Perilaku Etis, serta Pencegahan Fraud.

\section{B. Keterbatasan Penelitian}

Peneliti menyadari keterbatasan dalam penelitian ini yang tentunya memerlukan perbaikan dan pengembangan untuk penelitian selanjutnya. Keterbatasan dalam penelitian ini adalah Variabel independen dalam penelitian belum memberikan kontribusi yang baik terhadap variable dependen. Hal tersebut terlihat dari analisis koefisien determinasi dimana nilai R2 sebesar $21,3 \%$. Sisanya sebesar $78.7 \%$ dipengaruhi oleh variabel lain diluar model ini. Sehingga, disarankan bagi peneliti selanjutnya untuk menambahkan variabel-variabel independen yang secara teoritis dapat berpengaruh lebih besar terhadap Pencegahan Fraud. Selain itu data yang dikumpulkan untuk diteliti dan dianalisis berdasarkan pada persepsi masing-masing responden terhadap item-item instrumen penelitian, sehingga dapat memungkinkan terjadinya bias atau miss perception. 


\section{Saran}

Berdasarkan hasil penelitian dan kesimpulan, adapun saran dari peneliti adalah Pada variabel Komitmen Profesi masih ada karyawan yang kurang puas dengan kebijakan asosiasi profesi atau kebijakan dari perusahaan yang tidak berkenan dihati, karenanya perusahaan harus mampu menjalin hubungan baik antara atasan dan bawahan, adanya umpan balik, iklim komunikasi yang mendukung serta perspektif organisasi yang terarah. Selain itu perusahaan juga dapat melibat karyawan dalam bentuk komunikasi dua arah misalnya dengan menyediakan kotak saran untuk atasan.

Untuk meningkatkan Perilaku Etis karyawan sebaiknya dalam Perjanjian Kerja Bersama dicantumkan dan disosialisasikan peraturan mengenai informasi rahasia perusahaan yang hanya diperlukan bagi kepentingan bisnis perusahaan, bukan untuk kepentingan pribadi sehingga dapat mengurangi tindakan fraud yang akan dilakukan karyawan.

Untuk penelitian di masa yang akan datang bisa memperluas objek penelitian, variabelvariabel yang diteliti seperti perilaku organisasi, iklim organisasi, personal cost dan lain sebagainya yang lebih dapat meningkatkan Pencegahan Fraud.

\section{DAFTAR PUSTAKA}

ACFE. (2016). Report to The Nations on Occupational Fraud and Abuse. Austin, USA: Association of Certified Fraud Examiner,Inc.

Ajzen, I. (1991). The Theory of Planned Behaviour". Organizational Behaviour and Human Decision Processes 50. Organizational Behaviour and Human Decision Processes 50, 179-211.

Alison. (2006). Fraud Auditing. The Audit Journal. The Audit Journal.

Arens, A. E. (2008). Auditing dan Jasa Assurance: Pendekatan Terintegrasi. (Alih bahasa: Herman Wibowo). Jakarta: Erlangga.

Arifiyani, H. A. (2012). Pengaruh Pengendalian Intern, Kepatuhan dan Kompensasi Manajemen Terhadap Perilaku Etis Karyawan (Studi Kasus pada PT Adi Satria Abadi Yogyakarta). Jurnal Nominal, 1(1).

Chen, C. d. (2010). How to Motivate Employees' Ethical Behaviour----Based on Management Control Theory. Guangzhou: School of Business Administration, South China University of Technology.

Gaurina, P. (2017). Pengaruh Persepsi Karyawan Mengenai Perilaku Etis Dan Whistleblowing System Terhadap Pencegahan Fraud (Studi Kasus Pada Bali Hai Cruises). e-Journal S1 Ak Universitas Pendidikan Ganesha Jurusan Akuntansi Program S1, 8.

Ghozali, I. (2013). Aplikasi Analisis Multivariat dengan Menggunakan SPSS. Semarang: BP UNDIP.

Hayati, R. \&. (2014, Oktober). Pengaruh Profesionalisme, Motivasi, Integritas, Dan Independensi Satuan Pengawasan Internal Dalam Mencegah Kecurangan (Fraud) Di Lingkungan Perguruan Tinggi Negeri. JAFFA, 2(2), 101-114. 
Journal Accounting and Finance

Edisi Vol. 5, No. 2, September 2021

Universitas Telkom

maghfira, A. (2019, Maret). Kasus Suap Krakatau Steel dan Catatan Kelam BUMN. Retrieved from https://upperline.id/post/kasus-suap-krakatau-steel-dan-catatan-kelam-bumn: https://upperline.id/post/kasus-suap-krakatau-steel-dan-catatan-kelam-bumn

Putra, H. \&. (2018). Pengaruh Komitmen Profesional, Lingkungan Etika, Intensitas Moral, Personal Cost Terhadap Intensi Untuk Melakukan Whistleblowing Internal (Studi Empiris Pada Opd Kabupaten Bengkalis),. Jurnal Akuntansi, Keuangan dan Bisnis, 11(2), 17-26.

Ridho, M. S. (2013). Pengaruh Komitmen Profesional, Locus Of Control, Keseriusan Pelanggaran Dan Suku Bangsa Terhadap Intensi Whistleblowing. Journal Equity, 19(1), 38-52.

Rustiarini, N. d. (2015). Fraud dan Wistleblowing Pengungkapan Kecurangan Akuntansi Oleh Auditor Pemerintah. Denpasar: Universitas Mahasaraswati.

Sawyer, L. B. (2003). Internal Auditing, 5th Edition. Altamonte Springs: The Institute of Internal Auditors.

Sekaran, U. \&. (2017). Metode penelitian untuk bisnis. Pendekatan pengembangan keahlian. Jakarta: Salemba Empat.

Sugiyono. (2014). Metode Penelitian Pendidikan Pendekatan Kuantitatif, Kualitatif, dan R\&D. Bandung: Alfabeta. 